\title{
ANALISIS TINGKAT KEPARAHAN PENYAKIT BUSUK BATANG PADA TANAMAN BUAH NAGA MERAH (Hylocereus Polyrhizus) DI DESA SUNGAI KURUK TIGA, ACEH TAMIANG
}

\author{
Maria Heviyanti ${ }^{1}$, Adnan $^{2}$, Vitia Cahyono ${ }^{3}$ \\ ${ }^{1,2)}$ Dosen Program Studi Agroteknologi Fakultas Pertanian Universitas Samudra \\ ${ }^{3)}$ Mahasiswa Program Studi Agroteknologi Fakultas Pertanian UniversitasSamudra \\ Email : mariah@unsam.ac.id
}

\begin{abstract}
ABSTRAK
Tanaman buah naga (Hylocereuspolyrhizus) mampu beradaptasi pada berbagai jenis iklim. Buah yang berasal dari Amerika ini termasuk kedalam jenis tanaman kaktus. Desa Sungaii Kuruk Tiga, Kabupaten Aceh Tamiang adalah desa yang menjadi pusat penanaman buah naga. Dalam budidaya buah naga salah satu masalah yang dihadapi petani adalah serangan pathogen penyebab penyakit. Salah satu penyakit yang menyerang tanaman buah naga merah di Desa Sungaii Kuruk Tiga adalah serangan penyakit busuk batang yang disebabkan oleh pathogen Erwinia sp.Tujuan penelitian adalah menganalisis tingkat keparahan penyakit dan persentase serangan penyakit busuk batang tanaman buah naga merah. Analisis tingkat keparahan penyakit dilaksanakan pada empat dusun di desa Sungai Kuruk Tiga yaitu Dusun Bakti, Dusun Tengah, Dusun Depan dan Dusun Keluarga. Metode yang digunakan adalah metode survey dimana lokasi ditentukan secara purposive sampling method. Hasil pengamatan yang diperoleh menunjukkan bahwa persentase serangan penyakit busuk batang pada setiap dusun rata-rata mencapai $100 \%$. Intensitas penyakit busuk batang tanaman buah naga pada empat dusun menunjukkan bahwa Intensitas serangan penyakit tertinggi terjadi di Dusun Keluarga (51\%), diikuiti oleh Dusun Depan (47\%), Dusun Tengah (38\%) dan Dusun Bakti (21\%). Rata-rata Intensitas serangan penyakit busuk batang lunak adalah 39,25\%. Tingginya persentase serangan dan intensitas serangan penyakit ini diantaranya dikarenakancara budidaya yang tidak tepat, sanitasi lingkungan yang buruk, tidak adanya perawatan lahan pertanaman, curah hujan dan kelembaban yang tinggi.
\end{abstract}

Kata kunci:Erwinia sp, Hylocereuspolyrhizus, penyakit busuk batang

\section{PENDAHULUAN}

Tanaman buah naga merah (Hylocereuspolyrhizus) merupakan tanaman yang berasal dari Amerika Selatan, Amerika Tengah, dan Meksiko. Tanaman buah naga mampu beradaptasi pada berbagai jenis iklim dan termasuk ke dalam jenis tanaman kaktus. Secara umum buah naga mengandung karbohidrat yang tinggi yaitu $29 \mathrm{~g}$, protein $3 \mathrm{~g}$, asam $0,139 \mathrm{~g}$, serat $7 \mathrm{~g}$, zat besi 0,65 $\mathrm{mg}$, fosfor 8,7 mg, vitamin C 9,4 mg, kalsium 134,5 mg, dan magnesium 60,4 mg. (Juherman, 2017 dan Room, 2021)

Desa Sungai Kuruk Tiga adalah salah satu desa di Kecamatan Seruway yang melakukan budidaya buah naga dengan luas kebun buah naga saat ini seluas 4,3 ha, awalnya pada tahun 2018 luas kebun buah naga seluas 21,60 ha dengan produktivitas 2,85 ton/tahun.Penurunan luas lahan penanaman buah naga ini dikarenakan adanya serangan penyakit pada tanaman buah naga. Berdasarkan hasil survei yang telah dilakukan memperlihatkan bahwa budidaya tanaman buah 
naga belum memenuhi persyaratan budidaya yang baik seperti sanitasi lahan dan drainase yang kurang baik. Perawatan tanaman buah naga yang tidak baik juga dapat menyebabkan mudahnya tanaman buah naga terserang penyakit. Salah satu penyakit yang menyerang tanaman buah naga merah di Desa sungai Kuruk Tiga adalah penyakit busuk batang lunak yang disebabkan oleh bakteri Erwinia sp. (BPP Seruway, 2020).

Gejala awal dari serangan penyakit busuk batang lunak yaitu bahwa sulur buah naga berwarna kecoklatan, tekstur sulur menjadi lunak dan berair, mudah sobek dan tercium bau yang tidak sedap (Octaviani, 2012).Gejala busuk lunak ini dapat menyerang bagian pangkat sulur, tengah sulur, maupun ujung sulur. Serangan berat menunjuukan sulur yang terserang akan terlepas, mengering, dan tertinggal lapisan kayunya saja (Suryaningrum, 2016).

\section{METODE PENELITIAN}

\section{Tempat dan Waktu Penelitian}

Penelitian dilaksanakan di Desa Sungai Kuruk Tiga, Kecamatan Seruway, Kabupaten Aceh Tamiang. Lokasi pengamatan dan pengambilan sampel ditentukan berdasarkan metode purposive sampling dimana lokasi penelitian ditentukan secara sengaja dimana lokasi tersebut adalahpusat penanaman tanaman buah naga merah. Berikut Peta Lokasi Penelitian (Gambar 1).

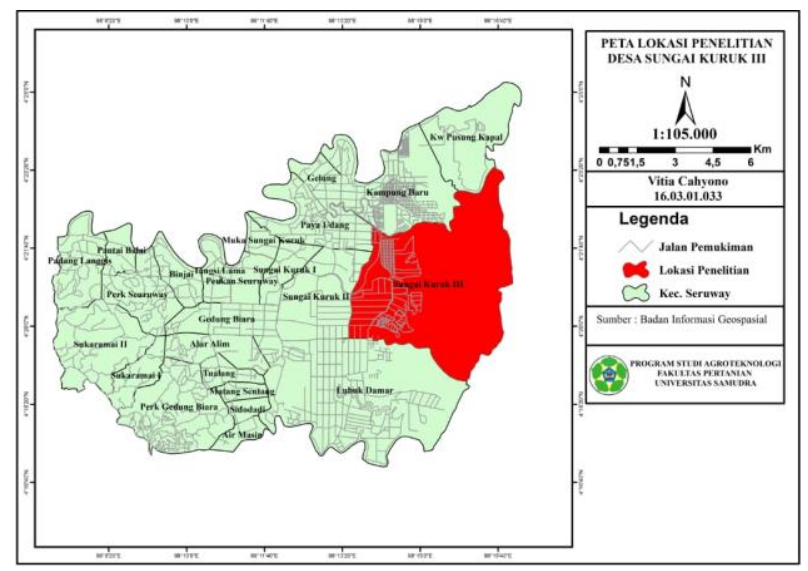

Gambar 1. Peta Lokasi

\section{Alat dan Bahan}

Alat dan bahan yang digunakan yaitu pisau, tali raffia, meteran, kertas label, alat tulis menulis, kamera digital, gunting, dan tanaman buah naga merah.

\section{Rancangan Penelitian}

\section{Metode Pengambilan Data}

Data yang diperoleh merupakan data primer dan data sekunder. Data primer adalah data 
hasil observasi dan wawancara langsung dengan petani buah naga merah di lokasi penelitian dengan menggunakan kuisioner yang telah disiapkan. Berikut petani buah naga merah yang menjadi responden di desa Sungai Kuruk Tiga, Kabupaten Aceh Tamiang.

Tabel 1.Jumlah Petani Responden Desa Sungai Kuruk Tiga, Kecamatan Seruway, Kab. Aceh Tamiang

\begin{tabular}{llc}
\hline No. & Dusun & Jumlah Responden/ Petani \\
\hline 1 & Bakti & 12 \\
2 & Tengah & 5 \\
3 & Keluarga & 4 \\
4 & Depan & 5 \\
\hline Populasi responden & $\mathbf{2 6}$ \\
\hline
\end{tabular}

Sumber: BPP Seruway (2020)

Hasil observasi lapangan dan wawancara tersebut berupa informasiteknik budidaya yang dilakukan oleh petani, penyakityang banyak menyerang tanaman buah naga merah, serangan dan gejala serangan penyakit busuk batang, dan cara pengendalian penyakit berdasarkan pengetahuan petani.

Data sekunder dikumpulkan dari studi literatur dan informasi lain yang berasal dari Badan Pusat Statistik Kabupaten Aceh Tamiang, Badan Penyuluhan Pertanian Kecamatan Seruway dan Dinas Pertanian Kabupaten Aceh Tamiang.

\section{Metode Pengambilan Sampel}

Pengamatan terhadap persentase danintensitas serangan penyakit busuk batang di desa Sungai Kuruk Tiga dilakukan pada lokasi kebun yang telah ditetapkan yaitu pada kebun dimana tanaman buah naga merahmenunjukkan gejala penyakit dan tanaman buah naga merah yang terserang penyakit.

Pengambilan sampel batang buah naga dilakukan di desa Sungai Kuruk Tiga yaitu pada empat dusun: Dusun Keluarga, Dusun Tengah, Dusun Bakti, dan Dusun Depan. Dari masingmasing dusun tersebut selanjutnya ditentukan satu kebun buah naga yang telah ditetapkan sebagai lokasi pengamatan.Kebun yang di pilih merupakan kebun dengan tanaman buah naga yang memperlihatkan gejala penyakit dan terserang penyakit, kebun yang telah berproduksi, dan dinilai mewakili keadaan kebun di masing-masing dusun tersebut.

Pengamatan penyakit busuk batang tanaman buah naga merah di lapangan dilakukan secara langsung di kebun buah naga dengan menggunakan metode garis diagonal " $\mathrm{X}$ ".

\section{Metode Analisis}

Untuk mengukur tingkat kerusakan akibat serangan penyakit busuk batang (Erwinia sp) 
buah naga merah dihitung dengan rumus:

Data perhitungan Intensitas penyakit busuk batang pada tanaman buah naga.

$\boldsymbol{I}=\frac{\Sigma(\mathrm{nxv})}{\mathrm{z} \times \mathrm{N}}(100 \%)$

Keterangan: $\quad \mathrm{I}=$ intensitas penyakit;

$\mathrm{n}=$ jumlah sampel sakit per kategori penyakit;

$v=$ nilai skala penyakit;

$\mathrm{Z}=$ skala tertinggi,

$\mathrm{N}=$ sampel yang diamati.

Tabel 2. Nilai Skor Pengamatan (Natawigena, 1993)

\begin{tabular}{lll}
\hline Skor & Nilai & Kriteria \\
\hline 0 & $0 \%$ & Tidak ada serangan/kerusakan \\
1 & $1-25 \%$ & Serangan/kerusakan ringan \\
2 & $26-50 \%$ & Serangan/kerusakan Sedang \\
3 & $51-75 \%$ & Serangan/kerusakan Berat \\
\hline 4 & $>75$ & Serangan/kerusakan Sangat Berat \\
\hline
\end{tabular}

HASIL DAN PEMBAHASAN

\section{Kondisi Umum Perkebunan Buah Naga}

Desa Sungai Kuruk Tiga terdiri dari 4 dusun yaitu Dusun Keluarga, Dusun Tengah, Dusun Bakti, dan Dusun Depan. Desa ini terletak di Kecamatan Seruway, Kabupaten Aceh Tamiang dengan ketinggian tempat 20-900 mdpl.Suhu rata-rata di Kecamatan Seruway berkisar antara $26^{\circ} \mathrm{C}$ sampai dengan $30^{\circ} \mathrm{C}$. Masyarakat di desa tersebut sebahagian besar bermata pencaharian sebagai petani dan nelayan.

Berdasarkan hasil wawancara diperoleh informasi bahwa yang menjadi faktor pendukung bagi petani dalam membudidayakan buah naga merah adalah perawatan yang mudah dan memiliki nilai ekonomi yang tinggi. Sulistiami dkk. (2012) menyatakan bahwa salah satu tanaman buah yang berkhasiat terhadap kesehatan dan mempunyai nilai ekonomi yang tinggi adalah tanaman buah naga. Hal tersebut menjadi penyebab tingginya permintaan konsumen dipasaran, sehingga memacu petani dalam melakukan budidaya buah naga (Nugraha, 2015).

Dari hasil survey yang telah dilakukan di Desa Sungai Kuruk Tiga menunjukkan di setiap dusun terdapat tanaman buah naga dengan paling luas berada di dusun Bakti dengan luas $\pm 2,5$ ha dan rata-rata para petani di setiap dusun telah menjadi petani buah naga selama \pm 6 tahun dengan luas lahan rata-rata mulai dari $400 \mathrm{~m}^{2}-25.000 \mathrm{~m}^{2}$. Jarak tanaman yang digunakan para petani 
berbeda-beda mulai dari $0,30 \mathrm{~m}$ x 1,5m sampai dengan $2,5 \mathrm{~m} \times 3 \mathrm{~m}$. Tiang penyangga batang buah naga merah menggunakan kayu perta atau kayu laut dengan tinggi 1,8m sampai dengan $2 \mathrm{~m}$.

Berdasarkan hasil wawancara dengan petani, selama 2-3 tahun belakangan ini tanaman buah naga merah di setiap dusun terkena penyakit dan belum dapat teratasi hingga sekarang. Petani mengenal penyakit tersebut dengan nama penyakit busuk kuning karena bagian sulur yang terkenal akan menunjukkan gejala yang berwarna kuning akibat matinya jaringan pada sulur. Para petani beranggapan bahwa busuk kuning pada sulur ini disebabkan oleh virus, hama dan curah hujan yang tinggi. Hal ini memperlihatkan bahwa kurangnya pengetahuan petani akan penyebab kerusakan pada tanaman buah naga yang dibudidayakan.

Berdasarkan hasil pengamatan di lapangan menunjukkan bahwa serangan penyakit busuk batang ini mengakibatkan terjadinya gagal panen dan mengakibatkan terjadinya penurunan produktifitas buah naga merah. Pemanenan dilakukan dengan interval waktu sebulan tiga kali. Busuk batang ini juga mengakibatkan buah naga merah dipanen lebih cepat karena juga dapat menyerang buah naga. Petani di desa Sungai Kuruk Tiga rata-rata belum memahami tentang perbedaan hama dan penyakit, banyak para petani yang beranggapan bahwa penyakit busuk batang lunak ini disebabkan oleh hama dan virus sedangkan penyakit ini disebabkan oleh bakteri Erwinia sp (Wibowo, dkk. 2011).

Berikut adalah tabel kondisi lahan petani buah naga merah pada setiap Dusun di Desa Sungai Kuruk Tiga:

Tabel 3.Kondisi lahan petani buah naga merah di Desa Sungai Kuruk Tiga

\begin{tabular}{|c|c|c|c|c|}
\hline Perihal & Dusun Tengah & Dusun Keluarga & $\begin{array}{l}\text { Dusun } \\
\text { Depan }\end{array}$ & $\begin{array}{l}\text { Dusun } \\
\text { Bakti }\end{array}$ \\
\hline Luas Lahan & $800 \mathrm{~m}^{2}$ & $1.200 \mathrm{~m}^{2}$ & $2.400 \mathrm{~m}^{2}$ & $3.200 \mathrm{~m}^{2}$ \\
\hline $\begin{array}{l}\text { Luas Lahan yang di } \\
\text { Amati }\end{array}$ & $800 \mathrm{~m}^{2}$ & $1.200 \mathrm{~m}^{2}$ & $2.400 \mathrm{~m}^{2}$ & $800 \mathrm{~m} 2$ \\
\hline Asal Bibit & $\begin{array}{l}\text { Membeli dari } \\
\text { petani lain }\end{array}$ & $\begin{array}{l}\text { Membeli dari } \\
\text { petani lain }\end{array}$ & $\begin{array}{l}\text { Membeli dari } \\
\text { petani lain }\end{array}$ & $\begin{array}{l}\text { Membeli dari } \\
\text { petani lain }\end{array}$ \\
\hline $\begin{array}{l}\text { Kebersihan Lahan } \\
\text { dan Kondisi Gulma }\end{array}$ & $\begin{array}{l}\text { Gulma kurang } \\
\text { dikendalikan }\end{array}$ & $\begin{array}{l}\text { Gulma kurang } \\
\text { dikendalikan }\end{array}$ & $\begin{array}{l}\text { Gulma Kurang di } \\
\text { kendalikan }\end{array}$ & $\begin{array}{l}\text { Bersih, gulma } \\
\text { terkendali }\end{array}$ \\
\hline Keadaan Air Tanah & Tergenang air & Kering & kering & Kering \\
\hline $\begin{array}{l}\text { Pertanaman di } \\
\text { Sekitar Lahan }\end{array}$ & $\begin{array}{l}\text { Padi Sawah dan } \\
\text { sawah }\end{array}$ & Jeruk & $\begin{array}{l}\text { Sawit dan } \\
\text { tanaman buah } \\
\text { naga lainnya }\end{array}$ & Sawit \\
\hline
\end{tabular}

Tiga kebun pengamatan merupakan lahan kering, namun pada Dusun Tengah merupakan lahan sawah, sehingga kebun selalu tergenang air. Kondisi lahan pengamatan disajikan pada gambar 3: 


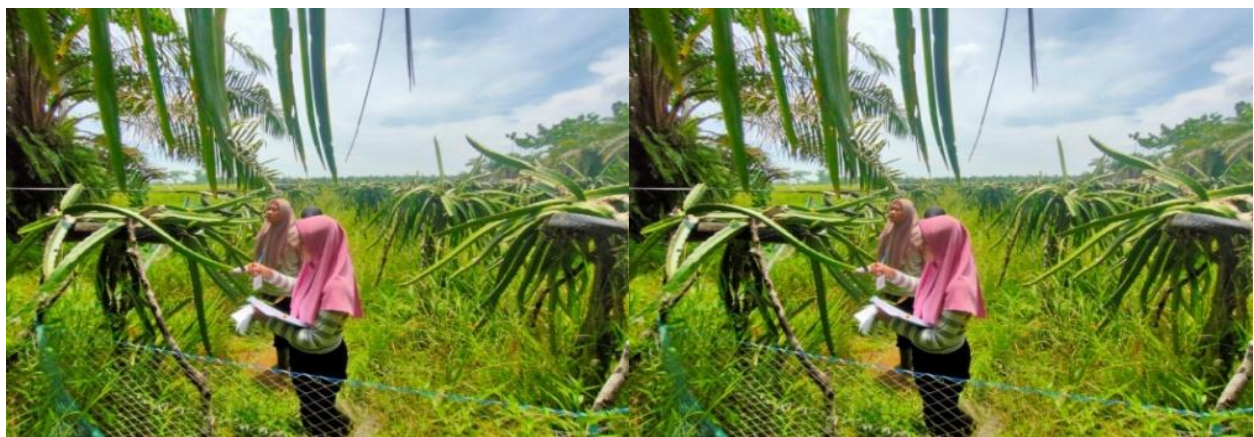

(a)

(b)

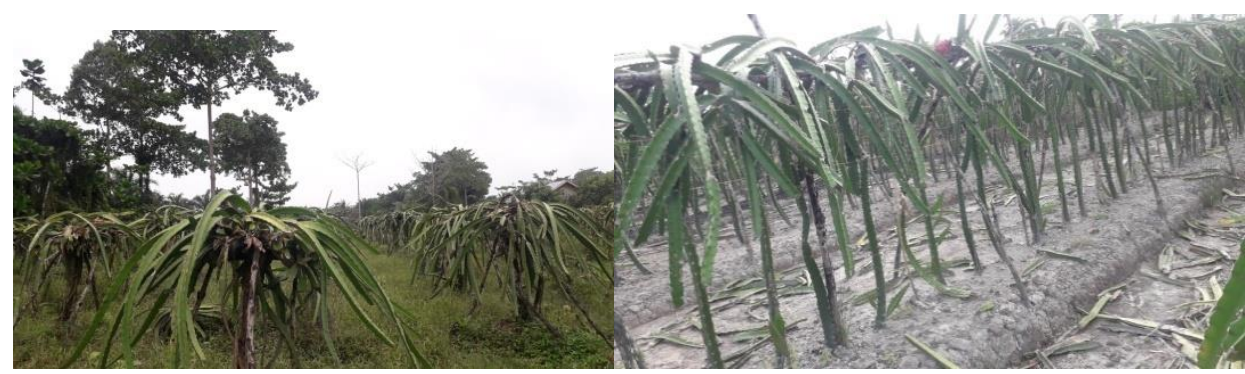

(c)

(d)

Gambar. 3 Kondisi empat lahan pengamatan penyakit busuk batang lunak (Erwinia sp) Kebun di Dusun Tengah (a), Kebun di Dusun Keluarga (b), Kebun di Dusun Depan (c), Kebun di Dusun Bakti (d).

\section{Persentase Serangan Penyakit Busuk Batang Tanaman Buah Naga}

Hasil pengamatan dari empat dusun di Desa Sungai KurukTiga secara umum menunjukkan bahwa penyakit busuk batang lunak (Erwinia sp) menyerang pertanaman buah naga dengan persentase serangan mencapai $100 \%$ di setiap Dusun (Tabel 4). Kejadian penyakit yang tinggi diakibatkan oleh perawatan kebun yang kurang baik, seperti penyiangan gulma yang tidak dilakukan, bekas pemangkasan atau sisa-sisa tanaman yang tidak dibersihkan, hal ini juga mengakibatkan semakin cepat serangan penyakit busuk lunak ini berkembang. Berikut data persentase serangan penyakit busuk batang tanaman buah naga merah (Tabel 4):

Tabel 4. Persentase Serangan Penyakit Busuk Batang

\begin{tabular}{ccccc}
\hline No. & Lahan & T1 & T2 & Persentase Serangan (P)(\%) \\
\hline 1 & 1 & 24 & 24 & 100 \\
2 & 2 & 20 & 20 & 100 \\
3 & 3 & 28 & 28 & 100 \\
4 & 4 & 12 & 12 & 100 \\
\hline \multicolumn{5}{r}{ Rata-Rata } \\
\hline
\end{tabular}


Penyebaran penyakit yang tidak merata yang disebabkan oleh system tanam monokultur dan penanaman yang luas serta jarak tanam yang terlalu rapat menyebabkan persentase serangan penyakit busuk batang menjadi meningkat. Peningkatan persentase serangan penyakit ini juga sangat dipengaruhi oleh interkasi yang terjadi antara tanaman inang rentan dan kondidi lingkungan yang mendukung terjadinya interaksi (Barthana dkk. 2013).

Para petani di tiga dusun yaitu Dusun Tengah, Dusun Depan dan Dusun Bakti rata-rata mengendalikan penyakit busuk batang lunak dengan menggunakan pestisida,memangkas batang yang terserang dan ada juga yang dikendalikan menggunakan air asin, karena para petani percaya bahwa penyakit ini dapat dikendalikan dengan air asin, sedangkan petani di Dusun Keluarga penyakit busuk batang lunak ini tidak dikendalikan sama sekali.

Salah satu yang mempengaruhi terjadinya penyebaran penyakit busuk batang lunak ini adalah intensitas curah hujan yang tinggi.Buah naga tumbuh dengan curah hujan yang rendah berkisar $720 \mathrm{~mm} /$ tahun (Hardjadinata, 2010). Selama tiga tahun terakhir curah hujan di desa Sungai Kuruk Tiga tergolong sangat tinggi yaitu berkisar 955-1523 mm/tahun sehingga pada tahun 2020 penyakit busuk batang lunak tanaman buah naga ini menjadi semakin cepat berkembang.

Tabel 5. Curah Hujan Di Kecamatan Seruway

\begin{tabular}{|c|c|c|c|c|c|}
\hline \multicolumn{7}{|c|}{ Curah Hujan (mm/tahun) } \\
\hline \multirow{2}{*}{ Seruway } & $\mathbf{2 0 1 6}$ & $\mathbf{2 0 1 7}$ & $\mathbf{2 0 1 8}$ & $\mathbf{2 0 1 9}$ & $\mathbf{2 0 2 0}$ \\
\cline { 2 - 6 } & 1532 & 1870 & 955 & 1048 & 1523 \\
\hline
\end{tabular}

Sumber:Dinas Pertanian

Tingginya intensitas curah hujan mengakibatkan kelembaban juga menjadi sangat tinggi, sehingga kondisi lingkungan seperti ini sangan mendukung pertumbuhan, perkembangan, dan penyebaran bakteri Erwinia sp. (Haloho, 2017).

\section{Intensitas Serangan Penyakit Busuk Batang Tanaman Buah Naga}

Intensitas serangan penyakit busuk batang buah naga merah (Erwinia sp) pada setiap dusun berbeda-beda, dikarenakan banyak faktor yang mengakibatkan intensitas serangan menjadi tinggi.Salah satu faktor yang menyebabkan tingginya intensitas serangan penyakit ini adalah kelembaban tanah yang tinggi, lingkungan yang tidak mendukung dan inang yang rentan terhadap serangan patogen (Helvetia, dkk 2013).

Akibat dari intensitas serangan penyakit yang tinggi di Desa Sungai Kuruk Tiga mengakibatkan produktivitas buah naga menurun sehingga banyak petani yang melakukan alih 
fungsi lahan. Berikut intensitas serangan penyakit busuk batang buah naga (table 6):

Tabel 6. Tabel Intensitas Serangan Penyakit Busuk Batang Lunak Buah Naga

\begin{tabular}{ll}
\hline Dusun & Intensitas \\
\hline Tengah & $38 \%$ \\
Keluarga & $51 \%$ \\
Depan & $47 \%$ \\
Bakti & $21 \%$ \\
\hline Rata-rata & $\mathbf{3 9 , 2 5 \%}$ \\
\hline
\end{tabular}

Tabel 6 diatas menunjukkan bahwa intensitas serangan penyakit pada setiap dusun sangat bervariasi yaitu berkisar antara $21 \%$ - 51\%.Intensitas serangan penyakit tertinggi dijumpai pada Dusun Keluarga (51\%).Dari data tersebut terlihat bahwa intensitas serangan penyakit busuk batang buah naga di dusun Keluarga tergolong ke dalam tingkat serangan berat. Berdasarkan hasil pengamatandan wawancara dengan pemilik kebun diperoleh informasi bahwa petani buah naga tidak mengendalikan penyakit busuk batang sama sekalidan jarang melakukan perawatan kebun seperti penyiangan gulma ataupun pemangkasan, sehingga mengakibatkan tanaman buah naga merah menjadi mudah terserang penyakit. Faktor lain yang mendukung perkembangan penyakit ini adalah curah hujan yang tinggi. Hujan menyebabkan peningkatan kelembaban di areal pertanaman sehingga sangat sesuai untuk perkembangan dan penyebaran bakteri Erwinia sp. Curah hujan yang tinggi dapat membantu penyebaran bakteri Erwinia sp.

Hal ini juga terjadi pada petani buah naga merah di dusun Depan, dikarenakan petani tidak melakukan penyiangan gulma dan pemangkasan, akibatnya lahan tersebut berpotensi berkembangnya penyakit busuk batang. Petani tanaman buah naga di Dusun tengah melakukan pengendalian penyakit busuk batang dengan menggunakan pestisida.Menurut Elmida, dkk (2013) secara umum perlakuan pestisida dapat menurunkan intensitas penyakit, namun efek pengendalian tersebut akan hilang setelah beberapa waktu aplikasi pestisida dihentikan. Tetapi dikarenakan kebun buah naga ini tidak terawat maka mengakibatkan intensitas serangan penyakit busuk batang lunak tanaman buah naga di Dusun Tengah ini mencapai $38 \%$.

Tanaman yang terawat dengan baikakan mengurangi terjadinya serangan penyakit, bisa dilihat bahwa intensitas serangan penyakit terendah terjadi pada Dusun Bakti. Hasil pengamatan dan wawancara menunjukkan pemilik kebun selalu melakukan perawatan seperti penyiangan gulma, pemberian pupuk dan pemangkasan secara teratur. 


\section{KESIMPULAN}

Berdasarkan hasil penelitian yang telah dilakukan, maka dapat diambil kesimpulan sebagai berikut:

1. Persentase serangan penyakit busuk batang lunak (Erwinia sp) rata-rata di setiap Dusun mencapai 100\%. Rata-rata serangan Intensitas penyakit busuk batang lunak di Desa Sungai Kuruk Tiga adalah $39,25 \%$.

2. Faktor penyebab tingginya persentase dan intensitas serangan penyakit busuk batang pada tanaman buah naga merah adalah curah hujan dan kelembaban yang tinggi, teknik budidaya yang tidak tepat dan perawatan lahan yang kurang baik seperti sanitasi lahan, penyiangan gulma dan drainase yang kurang baik. 


\section{DAFTAR PUSTAKA}

Barthana, D., Nasril, N., dan Jumjunidang 2013. Deskripsi Gejala dan Tingkat Serangan Penyakit Bususk Kuning pada Batang Tanaman Buah Naga Merah (Hylocecerus polyrhizus L.) di Pariaman Sumatera Barat.Jurnal Biologi Universitas Andalas, Vol. 2, No. 3, 222-228.

Haloho, A.I. 2017. Karakterisasi Penyakit Busuk Batang Lunak Pada Tanaman Buah Naga (Hylocereus sp.) dan Pengendaliannya Dengan Ekstrak Biji Bintaro (Cerbera manghas L.). Fakultas Pertanian. Universitas Brahwijaya, Malang.

Hardjadinata, S. 2010. Budidaya Buah Naga Super Red Secara Organik. Bogor: Penebar Swadaya.

Helvetia, R., Nasir, N., \& Jumjunidang. 2013. Gejala dan Tingkat Serangan Penyakit Busuk Hitam Pada Batang Buah Naga Merah (Hylocereus polyrhizus, L) di Padang Pariaman, Sumatera Utara.Jurnal Biologi. Universitas Andalas, 2(3) : 214-221.

Hidayat, A. N, Sofian, \& Akhsan, N. 2018. Intensitas Penyakit Busuk Batang Pada Tanaman Buah Naga Merah (Hylocereus Polyrhizus) Di Kecamatan Samboja. Jurnal Agroteknologi Tropika Lembab, 1(1) : 53-60.

Juherman, 2017. Mari Berbisnis Buah Naga Super Red (Hylocereus undatus). Widyaiswara PPPPTK Pertanian. Dapat diakses pada: http://p4tkpertanian.kemdikbud.go.id/v1/index.php?page=informasi\&id=119

Muas, I and Jumjunidang. 2015. Status of dragon fruit cultivation and marketing in Indonesia.International Workshop Proceedings of Improving Pitaya Production and Marketing.Fengshan, Kaohsiung, Taiwan.19-29.

Natawigena H. 1993. Dasar-dasar Perlindungan Tanaman. Penerbit Triganda Karya. Bandung.

Nugraha, T. A, 2015.Analisis Keuntungan dan Daya Saing Usaha Tani Buah Naga Di Desa Marga Jasa Kecamatan Sragi Kabupaten Kampung Selatan. Skripsi. Fakultas Pertanian. Universitas Lampung.

Room, M.J.V. 2021. Mengenal si Merah Dragon Fruit. BPTP Maluku. Dapat diakses pada: https://maluku.litbang.pertanian.go.id/?p=7633.

Sulistiami, A. 2012. Pertumbuhan organ tanaman buah naga (Hylocerus undatus) pada medium MS dengan penambahan BAP dan sukrosa. Jurnal Natural Science. Vol.1(1): 27-33.

Wibowo, A. Widiastuti, A., \& Agustina, W. 2011. Penyakit Penyakit Penting Buah Naga di Tiga Sentra Pertanaman di Jawa Tengah. Jurnal Perlindungan Tanaman Indonesia, vol 17 no 2, 2011: 66-72 Fakultas Pertanian. Universitas Gadjah Mada. Yogyakarta. 